\title{
HER2 Antigen Measurement
}

National Cancer Institute

\section{Source}

National Cancer Institute. HER2 Antigen Measurement. NCI Thesaurus. Code C112291.

The determination of the amount of HER2 antigen, including peptides, epitopes, and receptor, present in a sample. 